New Zealand journal of industrial relations, 1983, 8, 179-192

\title{
Union representatives and their members: learning and communication
}

\author{
Tom Schuller and Don Robertson*
}

The article reports on research conducted in 7 Scottish workplaces on the way shop stewards learn to carry out their representative duties, in particular how they communicate with the members they represent. Formal training is seen as only one element in the learning process, to be analysed in the context of the steward's overall environment: the national union, the branch and the workplace. The pattern of communication between stewards and their members, management and other union office-holders is traced out by the use of diaries and the key role (positive and negative) of the convenor or senior steward described. Finally, a provisional framework is put forward for the evaluation of formal training, and results reported from its application.

\section{Introduction}

The research on which we report here concerns the relationship between shop stewards and their members, and the impact of trade union training on that relationship. Although it was carried out in one country - Scotland - and is therefore located within the specific context of the United Kingdom industrial relations system, its application is far broader. For wherever union representatives operate, they learn - formally and informally - how to establish and maintain relationships with their members. National cultures and industrial relations practices will influence this learning process but common elements are there to be identified and evaluated.

We turn at the end to the training itself, but the bulk of this article reflects the direction the research took: mapping out the stewards' networks of relationships and thereby identifying the major social and organisational influences which shape the way they learn to do their job as representatives. The relative importance of the various agents and influences will vary from country to country, as well as within a single country and even within a single union. What we are suggesting is that the way representatives learn to represent their members is the outcome of a complex process, and that formal courses play only a small (if nonethless significant) part in that process.

Since the 1968 Donovan Report (Royal Commission, 1968) on industrial relations, much attention in the United Kingdom has been focussed on the role of stewards and the difficulties which confront them in carrying out their various functions. In particular, there has been a concern with relationships between the different levels of union organisations: shop floor, lay representatives and full-time officials (Boraston, et al, 1975). Education is frequently mentioned as a factor influencing the steward's ability to overcome various difficulties, but for all the discussion there has been little agreement and little direct research on its impact and the factors which determine its effectiveness. The objective of the proposed research was to do this in a limited number of instances, by studying the

* Research Director and Research Fellow, Centre for Research in Industrial Democracy and Participation, University of Glasgow. 
impact of union education on relations between stewards and members in terms of the quality of communication and changes in awareness and attitudes.

The study had its roots in previous work which combined research into the training needs of worker representatives with the development of teaching materials in an initial attempt to meet those needs (Schuller and Henderson, 1980). The education officers of Scottish branches of 2 major unions - the Transport and General Workers' Union (TGWU) and the National and Local Government Officers' Association (NALGO) - had been involved in this work. They were concerned about shop steward turnover and were keen to get a clearer idea of the effectiveness of their regular training programmes. They therefore collaborated in discussing and selecting appropriately varied branches, and in securing access to them. The research was funded by the Social Science Research Council.

We carried out fieldwork in 7 Scottish workplaces. Four of these were organised by the TGWU: a textile factory which we christened Treadle; a naval dockyard (Dockon); a chemicals plant (Chempot); and an electronics factory (Fiflec). Three were local government units covered by NALGO: a region (Ragged); a division of another region (Divauth); and a city authority (Rancit). Eighty-six stewards ( $62 \mathrm{men}, 24$ women) formed the basic sample, 42 from TGWU and 44 from NALGO. Between 12 and 15 were drawn from each workplace, except for Treadle and Fiflec which each furnished 6.

We undertook 2 sets of semi-structured interviews. The first, which lasted 1 to $1 \frac{1 / 2}{2}$ hours, covered the stewards' biographical details (e.g. formal educational background), the process which led them to become representatives, their experience of union training, and their links with members, management and fellow representatives. The second, carried out 10 to 12 weeks later, was shorter. It aimed to pick up judgments which might not have come through on the first round, since stewards have not normally prepared a tidily formulated account of their functions or of their views on trade union training.

Returning to the stewards also enabled us to pick up logs which we had left with them. This was a simple diary in which stewards were asked to record, on a weekly basis, how they divide their time between contacts with different groups: members, other union office-holders, and management. The aim was not to extract a full account of stewards' activities, but to focus on their patterns of communication. We also interviewed, in each workplace, the manager, usually with an industriai relations function, who was responsible for sanctioning the release of the stewards for training. The interviews probed their attitudes and judgments on the training and on shop steward development more generally.

The main results of the research fall into 3 parts, reflecting our decision to set the stewards' educational experience firmly in a more general organisational context. First, we developed individual profiles of each of the branches, drawing out the particular features which inhibit or encourage learning on the part of the stewards. Secondly, we traced out their patterns of communication, especially with members and with senior union representatives, and identified the factors which shape those patterns. Thirdly, we turned to the specific topic of trade union education, analysing its effects and suggesting how the relative impact on different students can be assessed.

\section{The context: union character and workplace organisation}

Union representatives operate within a variety of contexts (Clegg, 1976, especially ch. 8). In some countries (e.g. West Germany) these may be confined within a relatively uniform legal framework, with such differences as exist stemming mainly from the nature of the industry in which they work. But elsewhere the basic organisational unit, or branch, can vary very widely, in terms of size, structure, autonomy, member involvement and so on. In any case, however, it is important to understand the character both of the union nationally and of the branch as the environment within which the representative learns their role. Below we summarise the features of the workplace branches which are relevant to the educational "career" of their stewards. This needs first to be set against the background of the two unions as national organisations. 


\section{The national unions}

The TGWU and NALGO constitute as appropriate a pair of unions as one could wish for for comparative purposes. The former is a long-established manual union, with a complex system of regional and industrial organisation, and with members in almost every sector of employment (including, incidentally, local government, though we did not compare TGWU representatives in local government with their NALGO colleagues). By virtue of its history and its size (approaching 2 million members), the TGWU occupies a commanding position in the labour movement as a whole, and its leaders are national figures, politically and industrially.

NALGO, on the other hand, is a relatively young union. It is white-collar, and affiliated to the central Trades Union Congress (TUC) only in 1964. It has, on the other hand, grown very rapidly in recent years, due both to the upsurge of employment in local government and allied services (such as universities) and to a rise in the rate of unionisation in that sector. It is now the fourth largest union in the UK and can claim to be the biggest whitecollar union in the western world. Although it is no longer dominated by senior management (the proportion of chief officers on the NALGO national executive committee fell from 39 percent in 1930 to 5 percent in 1973) it includes significant numbers of middle and senior managers in its membership, and as shop stewards. Being concentrated in a single employment sector, it has a distinctly vertical structure. Amongst other things, its occupational composition also means that the average level of formal education is considerably higher amongst NALGO members and stewards than in the TGWU.

The differences between the 2 unions are not confined to the composition and spread of their membership. The TGWU is the most prominent example of decentralisation of power within unions, responsibility being devolved down to shop steward level as part of an explicit policy formulated and promoted by Jack Jones, the previous General Secretary, and his deputy Harry Urwin. Jones stated his position as follows:

I am working for a system where not a few trade union officials control the situation but a dedicated, well-trained and intelligent body of trade union members is represented by hundreds of thousands of lay representatives - every one of whom is capable of helping to resolve individual problems and assist in collective bargaining.

(quoted in Taylor, 1978, p. 200).

The extent to which this has actually occurred will vary between regions and industries and may not follow a consistent pattern, but it is certainly the case that TGWU stewards have come over the past 15 years to play a more significant part in negotiations generally. One indication of this is the improvement of the steward/member ratio, from 1:157 in 1955 to $1: 53$ in 1975 , unaccompanied by an equivalent growth in the number of full-time officers (Undy et al, 1980).

By contrast, NALGO stewards have little opportunity to take part in bread-and-butter negotiations. Bargaining over their members' pay and conditions takes place at national level, and there is little scope for action directly related to these basic issues. NALGO branches tend to be large and often cover big geographical areas; structurally, therefore, it would in any case be difficult for NALGO stewards to come together and form a compact negotiating team. They tend to operate more on an individual basis and to be concerned more with individual grievances than collective bargaining issues.

Finally, the ideologies of the 2 unions are quite different. The TGWU is at the heart of the labour movement. Being a general union it does not have quite the cachet of the famous craft unions, but its sheer muscle and extensive working-class membership, combined with the close familiarity of its leaders with those of the Labour party, give it an unmistakeable political stamp. NALGO, on the other hand, has not even affiliated to the Labour Party (though there are some pressures in this direction) and has far less of a common political core.

However, it is not so much a case of their current positions on a political left-right spectrum, which would in any case be a misleading averaging out of a broad span of opinion. Like most other white-collar unions, NALGO contains groups with a highly developed 
political stance, the most prominent being the NALGO Action Group (NAG). Conversely, the TGWU, although it has tended over the last 2 decades to take up what are generally regarded as left-wing positions on most issues, cannot be given a neat political label. By ideology in this context we mean more the tradition on which the union draws in terms of attitudes to the capital-labour distinction, and the extent to which its representatives can base their activities on the assumption that the membership is largely committed to a historically rooted idea of trade unionism (Nicholson, et al, 1981).

Overall trade union membership has increased continuously since the war until very recently, when the recession has started to bite into it. But this growth has not been accompanied by a parallel spread in trade union consciousness of the traditional kind (however loosely that is understood). The very speed of NALGO's growth and the spread of its members through the hierarchy of local government means that it commands less assent among its members on the precise nature of its role as a union than does the TGWU. Two consequences of this are particularly relevant to our theme: first, there is probably more divergence between stewards and members in their understanding of the role of a representative, and secondly, this divergence extends in some measure to the stewards themselves.

\section{Branch profiles}

It was against this national background that we built up profiles of the individual branches. We have extracted from them the most prominent features to make up a simple and abbreviated model of the learning environment. Within this model, the variables may take different values and - more significantly - interact with each other in different ways in different contexts.

\section{Relations with management}

The tenor and substance of management-union interaction is clearly an important component of the stewards' environment. In addition to the stewards' and union officials' account of industrial relations at the workplace, we took into acount the variety of managerial attitudes which shape the way stewards conceive of and discharge their functions.

Only 1 of the managers - in Ragged - did not see the stewards as an important communications link. Two out of the 3 managers working with NALGO, and all those working with TGWU, acknowledged the stewards' function as transmitters of information and showed no particular keenness to bypass them. The division in managerial attitudes to the stewards' role as communicator did not therefore lie along staff-shopfloor lines. It was between those who saw stewards as the links between the union and its members, and those who saw them as the links between management and the workforce. Four of the managers fell into the former category, 2 in TGWU workplaces (Fiflec and Dockon), and 2 in NALGO ones (Rancit and Divauth). In the other 2 workplaces (Chempot and Treadle), management regarded stewards as important, but less as union representatives than as links in the company information chain. The extent to which they were able implicitly to impose that interpretation on the stewards' own conception of their role clearly had substantial implications for their development.

The nature of the employment sector could obviously be expected to affect the relationship between stewards and management. In particular, relations in local government between union and management were affected by the degree to which senior union representatives had access to the political administration. In the Labour authority of Ragged, for example, the branch chairman and secretary would often bypass management and go directly to the elected members, leaving little significance to the regular manager-steward relationship. In this instance, management would have preferred to see shop stewards taking more initiatives independently of their union executive. In Fiflec, the introduction 
of new management from headquarters had disrupted the established industrial relations pattern and pushed the stewards into rethinking their own position.

\section{Workforce}

The make-up of the workforce is significant both because it provides the source from which stewards are drawn and influences the expectations which members have of their representatives. As would be expected, the sex and skill composition of the workforce affected the way the stewards saw their role. Treadle, for example, has a high percentage of female workers, mostly unskilled or semi-skilled. Moreover, a significant number work on night shift. This has resulted in a high turnover of stewards, and a steward body that is inexperienced and lacking in confidence. The same factors can, however, be modified by other circumstances. The TGWU membership at Fiflec is similarly dominated by female, unskilled workers. But most of the women are drawn from households and communities with strong roots in trade unionism through their involvement in the mining industry. They are therefore sympathetic to trade unionism, even though for many it is their first experience of union membership. Mining backgrounds also influence attitudes at Dockon, where a significant proportion of the exclusively male workforce have moved from the pits into the dockyard, bringing with them strong union traditions.

The NALGO branches tend to be far more mixed in their composition, as explained earlier. In part this is the inevitable consequence of their size and geographical diversity. As an example, Ragged was created out of 4 smaller authorities, so that the membership was drawn both from conservative administrative units with a formal and rigid management style, and from small towns where employees had a relaxed relationship with their managers and would also be likely to know their representatives socially.

The political composition of NALGO members also tended to be more "streaky", reflecting in part their ambiguous class composition. One steward observed that "we have on the whole a fairly right wing membership which is nevertheless prepared to elect radicals because they are the ones willing to do the work." He was perhaps being unduly modest, in that it is not simply a case of "doing the work" but of fighting hard and effectively for good conditions for their members. The point is, however, that stewards and members are often engaged in a continuous though covert bargaining process, which is complicated where there are substantial divergences of attitude.

\section{Union organisation}

The layout of the branch and the number of members influence stewards' behaviour and the aspirations which they entertain, especially as far as an active part in policy-making is concerned (Brown, et al, 1978). Large sprawling branches are not conducive to active participation, and the formulation of policy tends, therefore, to be left in the hands of the branch officers. This was the case in all the local authority branches. As a consequence the stewards will see their role largely in terms of the handling of individual problems and the transmission downwards of information.

The frequency and location of branch meetings affected the scope and outlook of individual stewards. In Fiflec, for example, the meetings were held on a Sunday in a "compromise" town which meant a tiresome journey for those using public transport. In some, members were not encouraged to attend at all, thus reinforcing the tendency of stewards towards exclusiveness in their union business. Thus Chempot's branch meeting is held on Monday evenings in the union offices in the town. It is in practice the weekly shop stewards' meeting. Although all members are entitled to attend, few take the opportunity to do so. The meeting is normally made up of a core of some 10 to 15 stewards, mainly process workers. Very few of the day shift stewards attend, mainly (they contend) because the meeting concerns itself almost entirely with matters of interest only to process 
workers. A number of stewards never attend the branch meeting. One in our sample had been a steward for 7 years and never attended a branch meeting despite considerable pressure from the branch officials.

We would also include the degree of hierarchy and discipline within the union and the extent to which responsibilities are devolved down to stewards. In some instances the convenor takes over all but the most humdrum problems, in others the stewards are left to their own devices.

\section{The place of trade union education}

We include this as a characteristic revealing the degree of expertise aspired to by branch officers and by representatives in the performance of their functions. Responsibility for education was clearly assigned in some cases to a senior officer within the branch, whilst in others there was no systematic approach. The incidence of courses within the branch itself demonstrated a certain attitude to the value of training, especially where there was active participation by branch officers or even full-time officials. Finally, the securing of adequate agreements for time off for training obviously affects its likely impact. In Dockon, provision was almost lavish in its scope, whereas in other cases the union had not yet succeeded in fully establishing the legitimacy of time off.

These features characterise the branches to varying degrees. (The metaphorical terms "features", "profile" and so on - are apposite, for they bring out the notion of the branch as a particular personality.) In any case, they do not make up a fleshed out picture of workplace organisation, and the list could be added to substantially. But without at least a broad understanding of the impact of the branch as a learning environment, any assessment of the effectiveness and importance of formal education will be unbalanced.

\section{Patterns of communication}

Who are the representatives and what do they actually do? Table 1 gives information on formal educational background. Table 2 refers to their experience as stewards. TGWU members not surprisingly had far less formal education than their NALGO counterparts, but more experience as union representatives. Broad variations of this nature are important, not only for the form which training takes but also more generally for understanding the nature of steward-member relations. The relevance to training is well known (even if its precise implications are not generally agreed): blue-collar stewards are more likely to have literacy and numeracy problems but can draw on greater experience as representatives, in addition to a longer-standing union tradition.

\section{Table 1 Educational background of stewards}

\begin{tabular}{lcccc}
\hline Attainment level & TGWU & NALGO & TOTAL & Percentage \\
\hline No formal qualifications & 35 & 6 & 41 & 47 \\
O or A levels & 5 & 7 & 12 & 14 \\
City \& Guilds & 2 & 9 & 11 & 13 \\
Higher National Certificate & 0 & 4 & 4 & 5 \\
Higher education diploma & 0 & 11 & 11 & 13 \\
Degree & 0 & 7 & 7 & 8 \\
Total & 42 & 44 & 86 & 100 \\
\hline
\end{tabular}

Understanding the pattern of communication between representative and member requires, however, a more detailed knowledge of the stewards' activities, and it is here that the logs provide information which is in our view highly significant. Table 3 presents the 
Table 2 Length of time as a steward

\begin{tabular}{lcccc}
\hline Time & TGWU & NALGO & TOTAL & Percentage \\
\hline Under 1 year & 9 & 6 & 15 & 18 \\
1 - 2 years & 9 & 21 & 30 & 34 \\
3 - 5 years & 9 & 16 & 25 & 29 \\
6 - 10 years & 8 & 0 & 8 & 9 \\
11 - 15 years & 3 & 1 & 4 & 5 \\
Over 15 years & 4 & 0 & 4 & 5 \\
Total & 42 & 44 & 86 & 100 \\
\hline
\end{tabular}

distribution of the stewards' time between the main agents with whom they have contact: members, management and other union office-holders. Contacts with members and management were further subdivided into 3 categories: those dealing with problems concerning a single individual, with problems concerning a workgroup, and with issues relating to national policies. Contacts with union office-holders were subdivided between: other stewards as individuals; convenors and full-time officials; shop steward meetings; and a miscellaneous category.

Table 3 Distribution of stewards' weekly "contact time"

\begin{tabular}{lccc}
\hline Activity & Average time (hrs.) & Range & Percentage of total \\
\hline Talking to/meeting members & $3 / 4$ & $0-2$ & 27 \\
Talking to/meeting management & $1 / 2$ & $0-2 \frac{1}{2}$ & 18 \\
Talking to/meeting stewards, union & $1 \frac{1}{2}$ & $0-3 \frac{1}{2} 2$ & 55 \\
$\quad$ officials & $2 \frac{3 / 4}{2}$ & & 100 \\
\hline
\end{tabular}

The log is in many ways a crude and unreliable instrument. It depends on self-reporting, and it is difficult to guard against bias (Stewart, 1965). The result may understate contact with members, in that frequent but fleeting contact with members may not have been chronicled. On the other hand, this will be balanced by a natural tendency to overstate, especially in cases where the steward appeared to himself to be scoring low. Given these reservations, the chief conclusion to emerge is that stewards spend considerably more time talking to each other than to their members: on average $1 \frac{1}{2}$ hours on the former, compared with $3 / 4$ hour in contact with their members, whether individually or collectively.

Variations on this pattern occur as much between branches as between unions, which is why we stressed earlier the individuality of branches. Nevertheless there are significant differences on more than one dimension. NALGO stewards tend to spend more of their time speaking to members than their blue-collar counterparts. They spend less on contact with management, especially on group matters. Significantly, by far the biggest single component in their time budget is shop steward meetings.

In part these differences can be explained by structural features of union organisation, such as constituency size (the number of members per steward) and its dispersion (the number of locations where a single steward has members). If a steward has many members spread over a large number of locations, direct contact with members will be difficult. In our sample, NALGO had more small constituencies (under 20 members) but they also tended to be more multi-locational: about one-fifth had 5 or more workplaces to cover. However, only 4 stewards reported that the number of locations was a problem for them in maintaining good communications with their members.

Potentially of far greater significance than the quantitative distribution of contact time is the use to which that time is put. In their contact with the members, stewards spend the 
great bulk of their time talking about individuals' problems or about the problems of the immediate work group. On average, stewards spend roughly 40 minutes a week on this kind of issue. By contrast, they spend an average of less than 5 minutes discussing union policy and this average obviously embraces a substantial number of cases where union policy is never discussed at all. By policies, we meant official positions held by the union on issues ranging from regrading or health and safety to central government's restrictions on local government finances or sympathetic industrial action in support of other workers. The "political" content of policies obviously varies considerably.

This tends to confirm the image of the steward as someone who takes up problems for individuals rather than acting as the representative of a group. In other words, recourse is made to the shop steward simply because they are the person best placed to solve a particular problem at a given time. The idea that the problems which an individual encounters may be part of a broader pattern of power distribution and that their resolution - or even prevention - depends on the development of a collective approach collectively supported is thereby weakened. One of the members at Treadle summed it up rather unglamorously by defining the steward's job as taking up points that you yourself would be afraid to complain about: "After all, why should I go to the supervisor and get a red face when that's what a steward is for?" The stewards may willingly comply with this image. On the other hand they may feel that they should be giving the union a higher profile, but be apprehensive about even trying to do so. The remarks of a Treadle steward reflects this lack of confidence: "I'm very careful not to contradict people about what they read about unions and that in the papers. They are always ready to laugh and say "What does she know, she's just a winder like us'." In short, many members do not see the steward primarily as a link with and representative of their union, that union being a national organisation of workers with shared interests. They see him or her more as a person who can simply punch a little harder than themselves.

In the next section we look more closely at how the attitudes of members affect the role of the steward. All that we would add here is that many stewards were simply not themselves committed to representing their union as such. They saw themselves rather as counsellors or solvers of individual problems.

In this context.it is important to note that our stewards administer rather than negotiate, in Clegg's terminology (Clegg, 1976, pp. 5-6). When they meet management, it is almost invariably to receive information or to deal with individual or group grievances, hardly ever to fashion agreements. Perhaps surprisingly, this is as true for the TGWU as for NALGO. The administration of agreements is, of course, not a mechanistic or lifeless activity. But the fact that few stewards participate in the making of agreements has a particular explanatory significance. We noted above that of the time stewards spend in contact with their members, most is spent on the handling of individual grievances and very little on collective issues. Most notably, discussion of union policies is minimal. This ties in with the concentration of stewards' efforts on the administration rather than on the negotiation of agreements. A lack of involvement in the original formulation of rules is associated with some form of unpreparedness to give a lead in "unionising" the debate, so to speak - in giving it a collective dimension which identifies the stewards as the representatives and employees as members of the union as a national organisation. (See Schuller and Robertson, 1983).

\section{Member attitudes}

The scope of the study was not broad enough to include a full analysis of member participation, a topic which has a long history (Anderson, 1979; Hemingway, 1978). Nevertheless it is clear from our work that the degree of understanding of how the union functions is a crucial determinant of the level of membership involvement in union affairs. In this context, there were 2 related problem areas relevant to the role of a representative 
(apart from occasional practical difficulties such as the time or location of branch meetings).

First, familiarity with union machinery. Members tended to be discouraged from taking part by the relative unintelligibility of what goes on at branch meetings. The most common complaint was of the absence of support for those who might wish to contribute but had little experience of meetings procedures. Confidence rapidly evaporated, and with it the desire to participate. It was not, however, a question only of meetings; a recurrent theme which emerged from the member group discussions was the desire to know more about the union machinery in general. At the most basic level, alarming misconceptions appeared, even of the role of their representatives: for example, it took one group some time to convince one of its members that the steward was neither paid for the job nor got time off in lieu for evenings or weekends spent on union work. But, more generally, there was a widespread uncertainty about how the union worked, which was sometimes blamed on the union, sometimes on the steward and sometimes on the members themselves.

Undoubtedly, a clearer understanding of union machinery and procedures would encourage member participation. The half-hour slot given to the branch secretary during the employee induction course (Treadle) was wholly inadequate for familiarising the membership with the way the union works. But - and this is the second problem area - our study suggests that it is more fruitful to focus on the nature of steward-member relations in respect of the policies and ideology of the union and of trade unions in general. This has led us to characterise the model of steward-member relations as an implicit contract. Implicit, because its terms are rarely if ever debated - indeed, its functioning depends to a large extent precisely on the terms never being made explicit. It is a contract in that the people involved assent to each other's behaviour, and to the consequences which flow from that behaviour, on condition that they receive certain benefits themselves. These benefits include, on the one hand, the authority to act on behalf of or in the name of others, and on the other hand, the protection and promotion of one's interests.

The fact that the contract is implicit does not, therefore, mean that it signals a poor or unsatisfactory relationship. Some stewards were glad of their independence. The lack of contact meant that they were freer to get on with the job. This should not be interpreted as a total disregard for the members, however. "The job" was to safeguard members" interests and this could on occasion be done best if the steward was left to operate without too many encumbrances. More often, however, the stewards were genuinely concerned about the lack of rapport with the members. The attribution of responsibility for this varied, but generally the members were criticised - at times harshly - for selfishness and apathy. It is obviously difficult to generate enthusiasm amongst the people you represent by berating them for their lack of it, and one can sympathise with one of the stewards' common reactions, which was to confine their contacts, other than on individual cases, to fellow stewards. What we are pointing to is the way members' attitudes, or stewards' perceptions of them (which may not be always the same thing, but which are anyway significant), provide an inducement for the steward to maintain the implicitness of the contract, for fear of it lapsing altogether.

It is in this context that members' attitudes to the training of the stewards should be understood. The twin most common features were a consensus on the need for training combined with a low level of awareness of whether or not the steward had, in fact, been on courses. Where the members did know that the steward had received training, this was often because they worked next to them and so noticed their absence. One example ties in the low level of member awareness beautifully to our major point above about the implicit contract. When a librarian in Divauth was going on a course, she told her members that she was visiting other libraries in the authority on professional business rather than admit to receiving union training. The members, she felt, would not have opposed her going but both she and they would have felt awkward about discussing it openly. 
The convenors ${ }^{1}$

Throughout the world, enterprises are becoming both more concentrated in their ownership and more complex in their structure, as mergers and takeovers proceed apace. Unions have not always been able to keep pace with these developments and are often struggling to maintain their "countervailing power" even at its previous level. However, there have been changes in union organisation and structure, and one of these has been the emergence of a more sophisticated system of representation, governed within the enterprise or plant by a senior union representative. The growth of these senior representatives, or convenors, has been documented in the United Kingdom both for manufacturing and non-manufacturing industry. In manufacturing, for example, convenors are now recognised in 74 percent of establishments with manual stewards and 61 percent of those with non-manual stewards (Brown, 1981; Hawes and Smith, 1980). But convenors do not just illustrate the evolution of a structured union organisation with its own differentiation and hierarchy and a developing expertise. They are key figures in shaping that evolution, especially in the influence which they exercise over the other members of the network of union representatives. This influence may be active or passive, and can be judged positive or negative. It covers both attitudes and practices. It is, itself, educational, in both the formal and informal sense, and also affects the part played by other educational influences. It is always dangerous to pinpoint individuals as crucial to any explanation but we believe the role of a workplace union leader can have a decisive influence on the behaviour of the stewards under his wing in 3 particular ways (See also Terry, 1982).

First, as a definer of the steward's role. The convenor plays an important part in determining expectations of how stewards should behave towards their members. This process will have started before the steward even takes office, in that, as a rank and file member, he will have observed how stewards carry out their job. He will therefore inherit a certain style, though it should be noted that he may not accept it. Indeed, one motive for becoming a steward may be dissatisfaction with those currently in office. In practice, this was not often cited but it did provide one example of how a convenor can indirectly but very clearly influence stewards, via membership expectations. A group of gardeners at Dockon complained to the convenor about the lethargy of their steward; he told them it was their responsibility and the steward was shortly voted out of office. The incoming representative was unlikely to adopt the same attitude as his predecessor.

Clearly the steward's assumption of office is a key phase when he can be influenced by the nature of his induction. But the convenor's influence as a definer of role will be a continuous one, exercised more by example than anything else. Stewards learn by observation and assimilation. As one observed: "You can try to be too formal. Our convenor seems to get things sorted out often by just having a quiet word with management. After all, there are often 2 sides to the question."

A particular feature which we observed was the definition of the steward's role as a communicator. In 5 of the workplaces, the steward was seen very much as a link between the union and the membership - in other words, as part of a distinct union organisation. This view was shared by management and union representatives. In Chempot and Fiflec, however, the prevailing model was of a link between management and the workforce, and therefore not as a component of an autonomous organisation. In both these cases, this was an interpretation implicitly accepted by the convenors and transmitted to stewards in their approach to the handling of industrial relations.

Secondly, the convenor can act as a guide or mentor. Here he makes explicit his own expectations of the steward, and gives him direct assistance. He may vary in the degrees of prescriptiveness with which he does this, ranging from the highly directive to the laisser-

1 The convenor is the senior union representative at the workplace. Sometimes they are officially recognised as such, but not always. They will generally be responsible for convening shop steward meetings, handling communications with the union's external offices and dealing with problems which the stewards cannot cope with themselves. Here we use the term loosely to include senior union representatives who play some significant role in shop steward development. 
faire. But, there is scope for a very definite teaching role. This may, however, present the convenor with a dilemma. On the one hand, he will wish to stress the technical demands of stewardship and the need for particular skills and knowledge. In this way he will maintain or raise the status of the office, and confirm the obligation to take it seriously. This points to a need for training. On the other hand, he may also wish to project the notion that effective representation comes only with experience or even is something of a talent not possessed by just anyone. This will lead him to resist the idea that anyone can formally learn to be a steward, and that the expertise needed can be adequately defined and codified.

Twenty-four percent of our sample selected the convenor as the single most important influence on their development as a steward. From their response it was clear that they were referring to the role-definer and mentor functions. We turn now to the third, more explicitly educational function, where the convenor acts as gatekeeper, determining the steward's access to and use of other educational resources.

In the first place, he is the likely recipient of details about courses, as part of the general briefings and information which come from the union office. In some of the workplaces, details about the courses were prominently displayed on notice boards. In others, the convenor would go further in actively drawing the attention of the stewards to their right to time off for training under the Employment Protection (Consolidation) Act 1978 and to the opportunities laid on by the union, the TUC or the Scottish TUC. At the other end of the scale, was the workplace where little information about the courses filtered through; one of us, in fact, inadvertently created a minor brouhaha by supplying a steward - on his request - with details of a course on new technology. This was seen by the convenor almost as an incitement to disloyalty.

As well as choosing whether or not to release these details, and how energetically to publicise them, the convenor can encourage or discourage participation. One rather basic form of encouragement is to secure good agreements for release for training. Dockon, where training had most impact, featured an agreement which was by any standards generous in the terms of which was granted: stewards attended up to 4 courses a year. This was complemented, however, by very sharp supervision on the part of the senior steward with responsibility for training. He pronounced himself well aware that stewards might be tempted to go on courses just for the sake of enjoying some time off, and left them in no doubt that they were there to learn. He himself regularly took an active part in the tutoring of the courses and on occasion deliberately came down with almost excessive force on stewards who were treating the course lightly.

On the other hand, the convenor can effectively discourage participation or nullify the effect of training. This may be done directly, for example by derogatory comments on the courses and tutors, or by a general downplaying of the value of training. It can also be done more circuitously - and perhaps less consciously - by making no attempt to help stewards apply what they learn. Typically they may be given perfect freedom to go on a course, but equally be given to understand that it is in the nature of a perk, and they should not expect actually to alter very much in their way of doing things as a consequence of their period of release. This was well illustrated by one convenor's casual comment: "It (training) can be useful so long as stewards don't get carried away with ideas that don't belong in this factory."

\section{Formal education}

We turn briefly to the courses themselves. Trade union education in the UK has grown rapidly over the last decade, following the Employment Protection Act 1975 which gave union representatives the right to time off with pay for recognised training. The development has been both quantitative and qualitative, with increasing numbers of students benefitting from a wide range of courses (Schuller, 1981). The recession has put at least a temporary halt to the growth in numbers, but further efforts are being put into revising and broadening the range of available courses, both by the TUC centrally and by individual 
unions. In addition to the staple 10-day shop steward and safety representative courses, training is available on such issues as rights at work, women's rights, new technology and pensions bargaining.

This is not the place to review current training practice. But having stressed the influence of the organisational context on the development of union representatives, we can summarise the results of the research as far as the courses themselves were concerned.

First, our measure of impact was the degree of change reported to have taken place in the stewards' attitudes and behaviour as a consequence of the courses. We were not assessing their competence as such, but the extent to which change had taken place, so the impact would be more likely to be significant where stewards began from a low level of competence. It is also important to remember that we concentrated on steward-member relations, not on the full range of skills required. We built up a picture of change in each case from a range of questions dealing with the following issues:

1) the importance of trade union education as a behaviour-influencing factor, relative to family-peer groups, other stewards, incidents at work, external union officers and political contacts

2) changes in behaviour towards members or management

3 ) the bringing up or negotiation with management of new topics

4) dealing with members who press for ill-considered action

5) willingness to take decisions

6) perceived changes in other stewards who have attended courses

7) potential of courses to remedy weaknesses as steward

8) changes in attitude to conveying union policies to members

The methodology appears - indeed is - crude, but it is at least a step towards a more refined approach. The crucial point is that any attempt to evaluate the courses should be linked to factors of the type we have analysed above. Our approach revealed substantial variations in impact, which we used to divide the stewards into 5 categories ranging from high to low impact. Very schematically, the major factors which accounted for the variations emerged as follows:

1) The quantity of education The total amount of training received ranged from 2 to 40 days. A particular advantage enjoyed by those who had had more training was that subsequent courses reinforced the value of earlier ones - in other words, a recurrent pattern proved particularly effective.

2) The distribution In some branches, training had been concentrated on a very limited number of stewards. Where it was more widely diffused, the impact was greater. This makes sense in the light of the mutual support provided by the stewards' network.

3) Branch courses Most training is provided in public colleges. But unions often put on their own courses related specifically to the needs of a particular branch. Their effectiveness was partly due to the tutoring being largely done by the convenors (see above) and partly to the preparatory function they performed vis-a-vis TUC or national courses. Branch courses run by familiar people on familiar topics allayed fears about returning to education.

4) The performance of tutors Widely differing reasons were recorded here, from the lyrical to the scathing. Those tutors were most appreciated who were familiar with both the teaching materials and the practical problems of the workplace, and who could control the class without being too "teachery".

5) Course relevance This refers not to the intrinsic content of a given course, but to the relevance it had for the specific steward - again a confirmation of the need to tie training needs to the environment from which the steward comes. It is best illustrated by a steward from Ragged: "I have to admit that although the law course was a real cracker, with a great tutor, I have hardly ever used any of it and probably never will. An ordinary steward like me never deals with anything like the law - it goes straight to the convenor and higher up the union." 


\section{Concluding note}

We have sketched out the context within which stewards learn part of their representative roles, looking at the actors who make up the cast with them and from whom they have to take their cues. We stressed the nature of the union-management relationship, the character of the workforce, and the quality of union organisation, and pointed to those above (convenors) and below (membership) the stewards as exercising what is often a decisive influence. We also analysed the distribution of the stewards' time - a necessary precondition of a satisfactory definition of learning needs. Finally we pointed to some of the factors which seem to influence the impact of formal training.

In conclusion it is worth suggesting that there are broader avenues which could be further pursued. Collective bargaining through union channels is one of the most important - in many cases clearly the single most important - means which employees have of influencing decisions affecting their working lives. If that can be accepted as a rough definition of democracy at work - the participation by working people, directly or through their representatives, in decisions affecting their working lives - then the training and development of union representatives may itself have lessons for future initiatives.

In short, whether or not workplace democracy is conceived of as the extension of collective bargaining or in terms of other institutional arrangements or as a mixture of both, the chances and abilities of workers and their representatives to learn the requisite skills is a major conditioning factor. The implication of this paper is that any education or training which purports to be for greater workplace democracy cannot be isolated from its organisational context. This may appear obvious, yet there are grounds for questioning how often it is in practice taken into account. There is a further consideration which follows from this. Learning in relation to workplace democracy cannot be a matter of getting to know existing rules and practices. If more people learn effectively to represent themselves, or to represent the interests of others, the pattern of rule-making will change, and the distribution of power with it. The effectiveness of learning applies not to students alone but to the organisation from which they are drawn.

\section{References}

Anderson, J. (1979) Local union participation: a re-examination Industrial relations 18 : $18-31$.

Boraston, I. et al. (1975) Workplace and union London, Heinemann.

Brown, W. (1981) The changing contours of British industrial relations Oxford, Blackwell.

Brown, W. et al. (1978) Factors shaping shop stewards' organisation in Britain British journal of industrial relations $16: 139-159$.

Clegg, H.A. (1976) Trade unionism under collective bargaining: a theory based on comparisons of six countries Oxford, Blackwell.

Hawes, W. and Smith, D. (1981) Employee involvement outside manufacturing Deparment of Employment gazette 89 (6) : 265-271.

Hemingway, J. (1978) Conflict and democracy Oxford, Oxford University Press.

Nicholson, N. et al. (1981) The dynamics of white collar unionism London, Academic Press.

Royal Commission on Trade Unions and Employers' Association (1968) (Donovan Report) Cmnd 3623, London, HMSO.

Schuller, T. (ed) (1981) Is knowledge power?: problems and practice in trade union education Aberdeen, Aberdeen People's Press.

Schuller, T. and Henderson, S. (1980) Worker representation and the articulation of training needs Industrial relations journal $11: 49-57$. 
Schuller, T. and Robertson, D. (1983) How representatives allocate their time : shop steward activity and membership contact British journal of industrial relations 21 (3) (forthcoming)

Stewart, R. (1965) The use of diaries to study managers' jobs Journal of management studies 2 : 228-235.

Taylor, R. (1978) The fifth estate: Britain's unions in the seventies London, Routledge \& Kegan Paul.

Terry, M. (1982) Organizing a fragmented workforce: shop stewards in local government British journal of industrial relations 20 : 1-19.

Undy, R. et al. (1981) Change in trade unions London, Hutchinson. 